\title{
Bedre seleksjon av rectumtumorer til transanal kirurgi
}

\begin{abstract}
Endorektal elastografi-evaluering er en lovende ny metode for stadievurdering av svulster i endetarmen, særlig tidlige stadier aktuelle for transanal kirurgi.
\end{abstract}

Pasientene får nå skreddersydd behandling for endetarmskreft i multidisiplinære team. Vurderingen avhenger av kvaliteten på den bildediagnostiske utredningen. Særlig tidlige stadier er vanskelige å vurdere med MR-undersøkelse og endorektal ultralyd (ERUS). I mitt doktorarbeid ville vi se om ultralydbasert endorektal elastografi kunne bedre den preoperative stadievurderingen.

Vi startet med en studie på et fantom og en gjennomførbarhetsstudie med 69 pasienter. Metodestudien viste hvordan vi burde velge referanseområde for målinger av strain-ratio (SR) (mål for hardhet). Gjennomførbarhetsstudien viste at vi kunne foreta SR-målinger med høy pasientetterlevelse og at målingene kunne skille mellom adenomer og adenokarsinomer i endetarmen $(\mathrm{p}<0,001)$.

Dette la grunnlaget for studier med 120 nye pasienter. Resultatene viste at elasto- grafi er bedre enn endorektal ultralyd og MR-undersøkelse til å skille adenomer og adenokarsinomer. Elastografi ser ut til å gi bedre vurdering av tidlige stadier (T0, T1 og T2), men sannsynligvis ikke av større svulster (T2, T3, T4). Vi har laget en algoritme som kombinerer endorektal ultralyd og elastografi som vil kunne redusere antallet pasienter operert med rectumreseksjon der en transanal rectumsparende prosedyre ville ha vært kurativ.

Funnene indikerer at endorektal elastografi i kombinasjon med eksisterende stadievurdering vil kunne bedre selekteringen av pasienter til transanal rectumsparende kirurgi og dermed redusere prosedyrerelatert morbiditet.

\section{Jo Erling Riise Waage}

jo.erling.riise.waage@ihelse.net

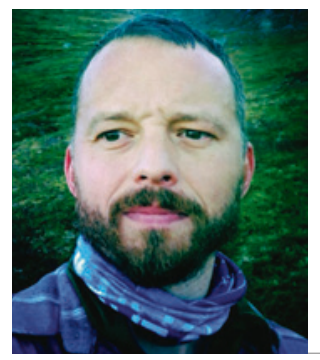

Jo Erling Riise Waage. Foto: Privat

Disputas

Jo Erling Riise Waage disputerte for ph.d.graden ved Universitetet i Bergen 2.10. 2014. Tittelen på avhandlingen er Strain elastography evaluation of rectal tumours - a critical assessment of a new imaging method.

\section{Risikofaktorer \\ for skulderdystoki ved fødsel}

\author{
Høy fødselsvekt, tidligere skulderdystoki og maternell diabetes gir økt \\ risiko for skulderdystoki.
}

Fastsittende skuldre under fødselen, skulderdystoki, er en sjelden, men dramatisk situasjon som oppstår hvis barnets skuldre ikke følger enkelt etter etter at hodet er født. Skulderdystoki kan medføre alvorlige komplikasjoner både for mor og barn. Kunnskap om risikofaktorer er viktig for å kunne forbygge denne fødselskomplikasjonen.

I mitt doktorarbeid brukte jeg data fra Medisinsk fødselsregister og inkluderte mer enn to millioner vaginale fødsler fra perioden 1967-2009. Forekomsten av skulderdystoki i populasjonen var på $0,7 \%$.

Høy fødselsvekt var den viktigste risikofaktoren for skulderdystoki, og hele tre firedeler av alle tilfeller opptrer når fødselsvekten er over 4000 gram. Ved høy fødselsvekt hadde flergangsfødende høyere risiko for skulderdystoki enn førstegangsfødende. Etter justering for fødselsvekt var det lavere risiko for skulderdystoki etter termin enn hvis fødselen skjedde før termin. Dette gjaldt spesielt hvis mor hadde diabetes. Gjentakelsesrisikoen er på over $7 \%$, men varierer med fødselsvekten i det aktuelle svangerskap. En kombinasjon av skulderdystoki ved en tidligere fødsel og høy fødselsvekt i det aktuelle svangerskapet innebar særlig høy risiko for ny skulderdystoki.

En gravid kvinne som tidligere har opplevd en skulderdystoki, bør anbefales forløsning med keisersnitt når antatt fødselsvekt er på 4500 gram eller mer.

\section{Eva Astrid Øverland}

eva.astrid.overland@ahus.no

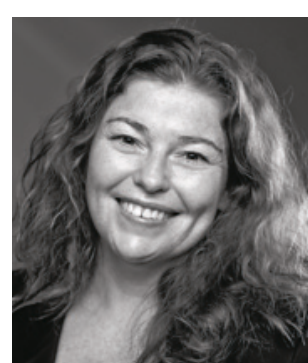

Eva Astrid Øverland Foto: Øystein Hasselø Horgmo

Disputas

Eva Astrid Øverland disputerte for ph.d.-graden ved Universitetet i Oslo 14.11.2014. Tittelen på avhandlingen er Shoulder dystocia at delivery: population-based studies of risk factors. 